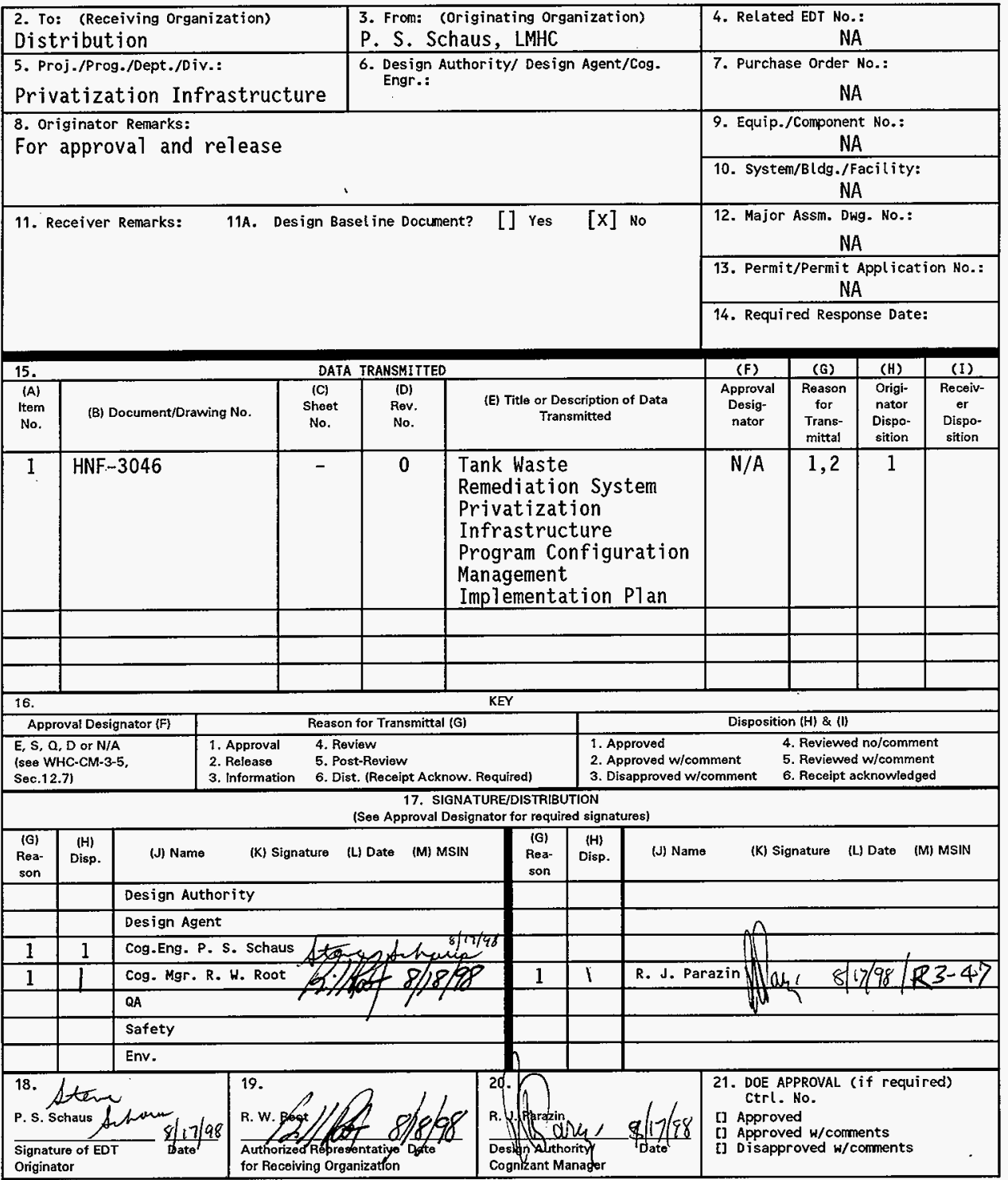

BD-7400-172-2 (05/96) GEF097 


\title{
Tank Waste Remediation System Privatization Privatization Infrastructure Program Configuration Management Implementation Plan
}

\author{
P. S. Schaus, R. J. Parazin (NHC), and H. Rossi (TRW) \\ Lockheed Mart in Hanford Corporation, Richland, WA 99352 \\ U.S. Department of Energy Contract DE-ACO6-96RL13200
}

EDT/ECN: 161499

Org Code: 73500

UC: 721

B\&R Code: EW3130010

Charge Code:

Total Pages: 37

Key Words: TWRS, systems engineering, W-519

Abstract: This Configuration Management Implementation Plan (CMIP) was developed to assist in managing systems, structures, and components (SSCs), to facilitate the effective control and statusing of changes to SSCS, and to ensure technical consistency between design, performance, and operational requirements. Its purpose is to describe the approach Privatization Infrastructure will take in implementing a configuration management program, to identify the Program's products that need configuration management control, to determine the rigor of control, and to identify the mechanisms for that control.

\footnotetext{
TRADEMARK DISCLAIMER. Reference herein to any specific comercial product, process, or service by trade name, trademark, manufacturer, or otherwise, does not necessarily constitute or imply its endorsement, recommendation, or favoring by the United States Government or any agency thereof or its contractors or subcontractors.

Printed in the United States of America. To obtain copies of this document, contact: Document Control Services, P.O. Box 950, Mailstop H6-08, Richland WA 99352, Phone (509) 372-2420;
} Fax (509) 376-4989.
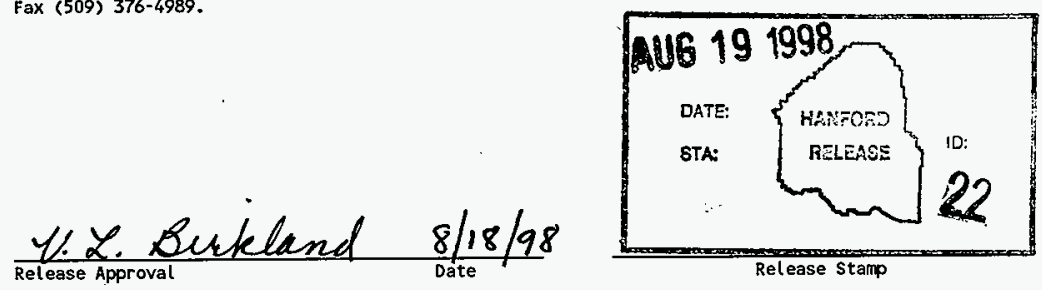

\section{Approved for Public Release}




\title{
TANK WASTE REMEDIATION SYSTEM PRIVATIZATION INFRASTRUCTURE PROGRAM CONFIGURATION MANAGEMENT IMPLEMENTATION PLAN
}

August 1998

\author{
P. S. Schaus \\ Lockheed Martin Hanford Corporation \\ Richland, Washington
}

\section{R. J. Parazin}

Numatec Hanford Corporation

Richland, Washington

\section{H. Rossi}

TRW Environmental Systems

Richland, Washington

\section{Prepared for}

U.S. Department of Energy

Richland, Washington 
HNF-3046

Revision 0

This page intentionally left blank. 


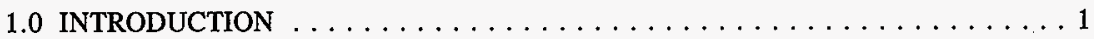

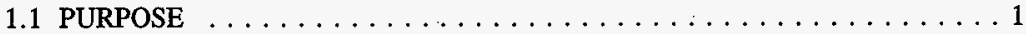

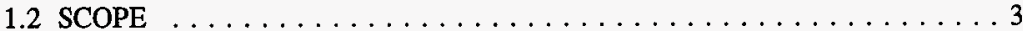

1.3 ROLES AND RESPONSIBILITIES $\ldots \ldots \ldots \ldots \ldots \ldots \ldots$

2.0 CONFIGURATION MANAGEMENT IMPLEMENTATION $\ldots \ldots \ldots \ldots \ldots 5$

2.1 USE OF ESTABLISHED CONTROL MANUALS $\ldots \ldots \ldots \ldots \ldots \ldots$

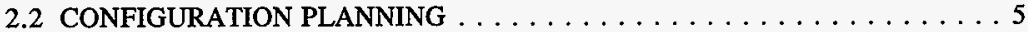

2.3 EQUIPMENT SCOPE CRITERIA $\ldots \ldots \ldots \ldots \ldots \ldots \ldots \ldots \ldots$

2.4 CONFIGURATION MANAGEMENT CONCEPTS AND TERMINOLOGY . . 6

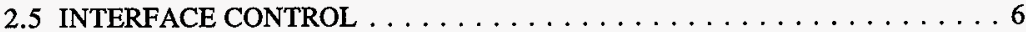

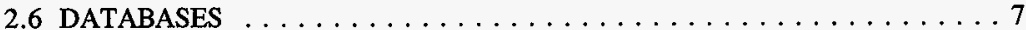

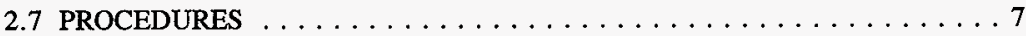

2.8 PROGRAM FILE DEVELOPMENT AND MAINTENANCE . . . . . . . 7

2.9 CONFIGURATION MANAGEMENT IMPLEMENTATION PLAN

TRAINING $\ldots \ldots \ldots \ldots \ldots \ldots \ldots \ldots \ldots \ldots \ldots \ldots \ldots$

2.10 PERFORMANCE AGREEMENTS $\ldots \ldots \ldots \ldots \ldots \ldots \ldots$

2.11 CONFIGURATION IDENTIFICATION $\ldots \ldots \ldots \ldots \ldots \ldots \ldots$

2.11.1 Configuration Item Selection and Control $\ldots \ldots \ldots \ldots \ldots$

2.11.2 Configuration Information Selection and Control $\ldots \ldots \ldots \ldots$

2.12 INTEGRATED BASELINE--ALLOCATION OF REQUIREMENTS $\ldots \ldots \ldots$

2.13 INTEGRATED BASELINE SCHEDULE $\ldots \ldots \ldots \ldots \ldots \ldots \ldots \ldots$

2.14 BASELINE BUDGET PLAN $\ldots \ldots \ldots \ldots \ldots \ldots \ldots \ldots \ldots \ldots$

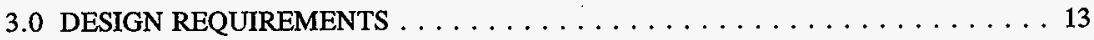

3.1 ESTABLISHMENT OF DESIGN REQUIREMENTS $\ldots \ldots \ldots \ldots \ldots \ldots 13$

3.2 REQUIREMENTS TRACKING $\ldots \ldots \ldots \ldots \ldots \ldots \ldots \ldots \ldots \ldots \ldots$

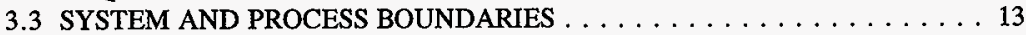

3.4 ASSIGNMENT OF STRUCTURES, SYSTEMS, AND COMPONENTS

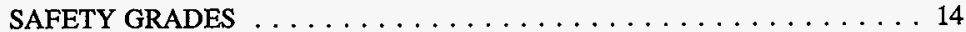

3.5 SAFETY EQUIPMENT LISTS $\ldots \ldots \ldots \ldots \ldots \ldots \ldots \ldots \ldots \ldots$

4.0 DOCUMENT CONTROL AND STATUS ACCOUNTING . . . . . . . . 15

4.1 DOCUMENT/INFORMATION CONTROL SYSTEMS AND FACILITIES . . . 15

4.2 CONFIGURATION STATUS ACCOUNTING $\ldots \ldots \ldots \ldots \ldots \ldots$

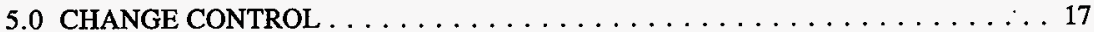

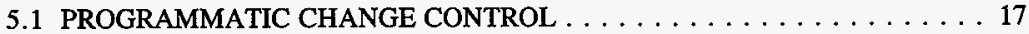

5.2 TECHNICAL CHANGE CONTROL $\ldots \ldots \ldots \ldots \ldots \ldots \ldots \ldots \ldots$

5.3 IDENTIFICATION OF CHANGES $\ldots \ldots \ldots \ldots \ldots \ldots \ldots \ldots \ldots$

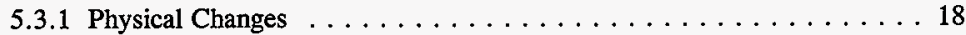

5.4 CHANGE CONTROL PROCESS $\ldots \ldots \ldots \ldots \ldots \ldots \ldots \ldots$ 


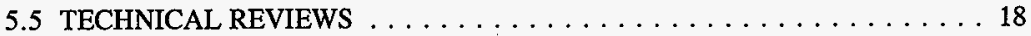

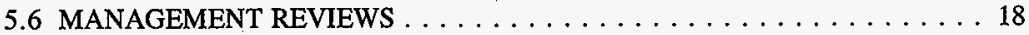

5.7 POST MODIFICATION TESTING $\ldots \ldots \ldots \ldots \ldots \ldots \ldots$

6.0 CONFIGURATION MANAGEMENT ASSESSMENTS $\ldots \ldots \ldots \ldots \ldots \ldots 21$

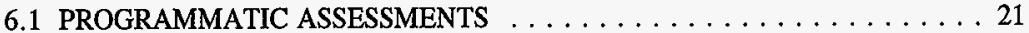

6.2 PROGRAM AND PROJECT LEVEL CONFIGURATION MANAGEMENT

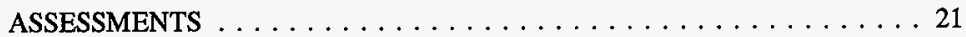

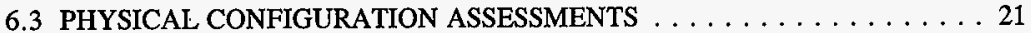

6.4 PERIODIC EQUIPMENT PERFORMANCE MONITORING . . . . . . . . 21

6.5 MATERIAL CONDITIONING AND AGING MANAGEMENT . . . . . . . 22

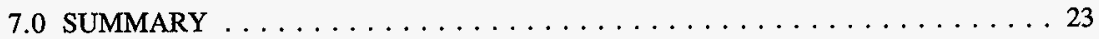

\section{LIST OF FIGURES}

1. Tank Waste Remediation System Configuration Management $\ldots \ldots \ldots \ldots \ldots$.

2. Configuration Management Process Flow. . . . . . . . . . . . . 9

APPENDIXES

A - ACRONYMS AND DEFINITIONS . . . . . . . . . . A-1

B - PRIVATIZATION INFRASTRUCTURE PROGRAM CONFIGURATION MANAGEMENT ROLES AND RESPONSIBILITIES $\ldots \ldots \ldots \ldots \ldots$ B-1

C - REFERENCES . . . . . . . . . . . . . . C 1 
HNF-3046

Revision 0

\section{TANK WASTE REMEDIATION SYSTEM PRIVATIZATION \\ INFRASTRUCTURE PROGRAM CONFIGURATION MANAGEMENT IMPLEMENTATION PLAN}

\subsection{INTRODUCTION}

The Privatization Infrastructure (PI) Program is a program within the Tank Waste Remediation System (TWRS), and provides the utilities (roads, water, electricity, and secondary waste disposal) required by the TWRS Privatization Contractor (PC). As such, the configuration management (CM) of the PI Program must be compatible with the TWRS CM Program. This plan defines the PI Program's approach and processes for CM, and implements the Tank Waste Remediation System Configuration Management Plan (TWRS CMP), HNF-1900 (Vann et al. 1998) at the program level. Figure 1 schematically represents the TWRS approach to CM, as adopted by this program. Application of CM will be consistently applied across all PI Program activities and assessed accordingly.

The PI Project (W-519) is the capital project within the PI Program that provides the physical hardware (roads, electrical conduit, water piping, secondary effluent discharge lines, etc.) for the PC. Other parts of the PI Program include: integrity assessments of the tank(s) that will be turned over to the PC for its use; removal of long-length contaminated equipment from the tanks; and administration of funding for the utilities and secondary waste disposal costs associated with PC operations.

\subsection{PURPOSE}

This Configuration Management Implementation Plan (CMIP) was developed to assist in managing systems, structures, and components (SSCs), to facilitate the effective control and statusing of changes to SSCs, and to ensure technical consistency between design, performance, and operational requirements. Its purpose is to describe the approach PI will take in implementing a CM program, to identify the Program's products that need CM control, to determine the rigor of control, and to identify the mechanisms for that control.

The responsibilities, actions, and tools defined in this plan will be used to establish and maintain the technical consistency among design requirements, physical configuration and related documentation, in accordance with TWRS CMP, HNF-1900 (Vann et al. 1998), which incorporates the CM requirements imposed by the U. S. Department of Energy (DOE), the DOE Richland Office (RL), the Project Hanford Management Contract (PHMC), and the TWRS Program. 


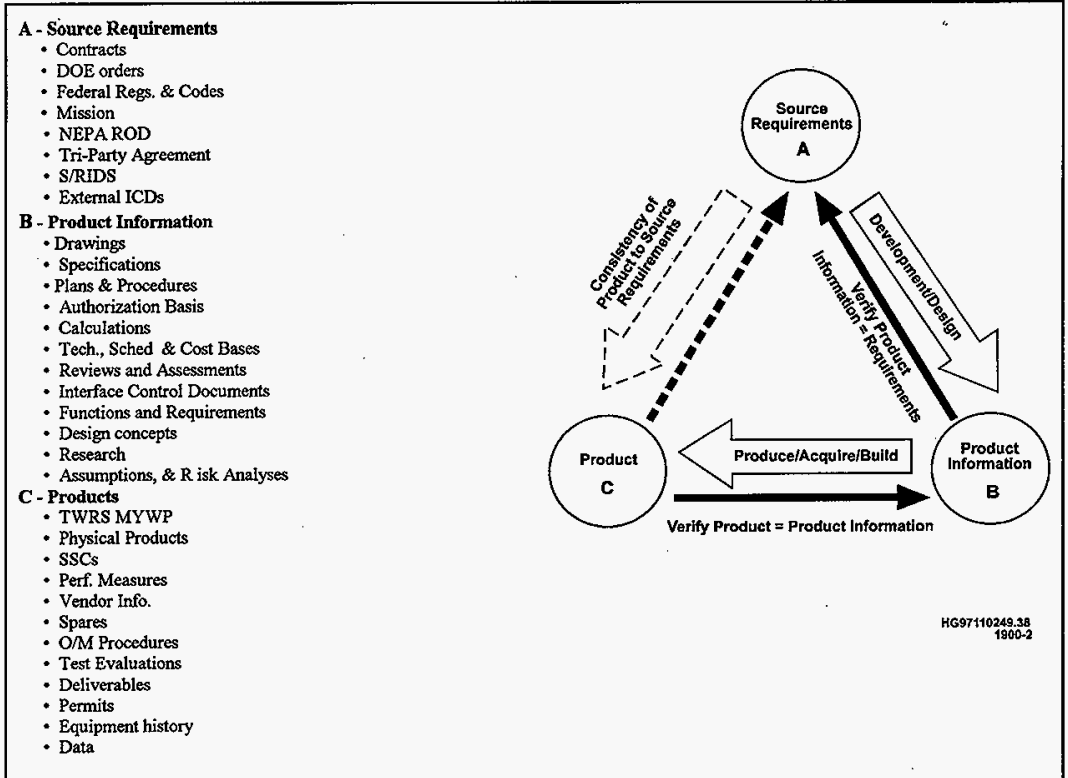

ICD = Interface Control Document. MYWP $=$ Multi-Year Work Plan. NEPA = National Environmental Policy Act. SSC $=$ systems, structures, and components.
S/RIDS $=$ Standarda/Requirements Identification Document. Tri-Party Agreement = Harford Federal Facility Agreement and Consent Order TWRS - Tank Waste Remediation System. 


\subsection{SCOPE}

The PI Program, its project, subprojects, subcontractors and vendors will adopt and comply with this plan. The scope of this CM program is to direct and monitor the development and implementation of CM, for the life of the program. It establishes the criteria for the scope of the CM program; defines CM concepts, and terminology; identifies and controls $\mathrm{CM}$ for organizational and programmatic interfaces; establishes the policy and criteria for required information systems; and specifies $\mathrm{CM}$ procedures. This plan further describes the $\mathrm{CM}$ processes used to maintain consistency among source requirements, product information, and the product itself.

This CMIP reflects those actions and responsibilities necessary to implement the requirements as a TWRS program. Information associated with the CM of items will be maintained as required, throughout the product's life cycle (design, acquisition, construction, operations, etc.). Assessments will be performed to determine the extent and quality of CM program implementation and the need for program improvements.

\subsection{ROLES AND RESPONSIBILITIES}

The PI Program Manager will ensure the successful implementation of this CM program in accordance with the requirements of Tank Waste Remediation System Systems Engineering Management Plan, HNF-SD-WM-SEMP-002 (Peck 1998), and TWRS CMP, HNF-1900 (Vann et al. 1998). This includes ensuring CM requirements are contractually imposed on all subcontractors and vendors. Responsibility for the conduct of specific $\mathrm{CM}$ activities are defined in Appendix B of this document, and further defined in the engineering practices and procedures referenced throughout this plan. 
HNF-3046

Revision 0

This page intentionally left blank. 
HNF-3046

Revision 0

\subsection{CONFIGURATION MANAGEMENT IMPLEMENTATION}

The PI Program will focus on three groups of tasks to implement CM:

1. Recovery tasks--work that includes design reconstitution, material conditioning and aging of existing facilities, labeling, and training

2. Ongoing implementation tasks--work that includes documentation of design activities, document control, records management, product validation and test, procedure control, work packages, change implementation, as-built verification and validation, and closure

3. Information improvement tasks--work that includes implementation of management tools to link information of the Program's facilities.

These CM tasks will be addressed in the TWRS work breakdown structure (WBS) elements, as defined in Tank Waste Remediation System Fiscal Year 1999 Multi-Year Work Plan (MYWP), HNF-SP-1230 (Lenseigne 1997).

The following Sections (2.1 through 2.14) provide top level descriptions of the actions to be taken by PI Program managers in implementing the Program's CM Plan. More detailed descriptions and procedures are provided in TWRS Administration, HNF-IP-0842, Volume IV, "Engineering," Section 2.13, "Tank Waste Retrieval Configuration Management" (LMHC 1997). Other procedures will be reviewed and evaluated for their usefulness in implementing the PI CM program and updated or deleted accordingly.

\subsection{USE OF ESTABLISHED CONTROL MANUALS}

$\mathrm{CM}$ will be achieved through established Hanford Site processes, using existing controlled manuals and/or Project Hanford Policies and Procedures (PHPP) available through the Hanford Site Intranet. Key procedures are identified throughout the text of this document, and listed in Appendix C. Requests for deviations, exceptions, exemptions, and variances to policies, procedures, and requirements from PHPP, will be developed and processed per the Processing Project Hanford Procedures, HNF-PRO-589, or the Exemptions and Equivalencies, HNF-PRO-344,

\subsection{CONFIGURATION PLANNING}

The PI Program will develop, maintain, and status an implementation schedule for its CM. Specific items and associated information (status, dates, etc.) in the CM schedule will vary as CM implementation progresses. This schedule will be provided to the PI Program Manager for concurrence. 
HNF-3046

Revision 0

\subsection{EQUIPMENT SCOPE CRITERIA}

Items are products produced and/or used by the PI Program, including physical items, software, documents, data, systems, structures, or components. Configuration Items are the subset of all program related products selected for $\mathrm{CM}$.

The TWRS Technical Baseline establishes the design basis for the functional and physical characteristics of those items owned by the PI Program. Criteria for identifying those PI items and related information requiring configuration control are provided in the TWRS CMP, HNF-1900 (Vann et al. 1998). See Section 2.11.1 for a more detailed description of item selection and control.

The criteria and methodology provided in Safety Structures, Systems, and Components, HNF-PRO-516, will be used by PI Program to determine the identification and safety classification of each SSC, and in the development of Safety Analysis Reports (SARs).

Computer software used in quality affecting activities (i.e., analyses, engineering design, environmental applications, hardware and facility operations and management information) within the scope of the PI Program will meet the requirements of Project Hanford Quality Assurance Program Description, MRP-MP-599, Control of Computer Software, HNF-PRO-309, and Software Control, HNF-PRO-464,

\subsection{CONFIGURATION MANAGEMENT CONCEPTS AND TERMINOLOGY}

The PI Program will use the concepts and terminology defined in Document Control, HNF-PRO-224, Quality Assurance Records, HNF-PRO-222, and the PHPP Glossary, which reflect the standard Hanford Site terminology, initialisms, and acronyms. This ensures consistency between the PI Program and other Hanford Site organizations (i.e., Safety, Quality Assurance, Procurement).

\subsection{INTERFACE CONTROL}

The PI Program will identify and control its interfaces, in accordance with Interface Control Requirements, HNF-PRO-243, and the TWRS Administration Manual, HNF-IP-0842 (LMHC 1997). This includes all internal and external interfaces, and requires:

- Establishment of technical agreements by interfacing elements

- Preparation of supporting documentation

- Administrative control of the documented agreements.

Interface control documents (ICDs) will be developed to record technical requirements and design solutions across physical interface boundaries, between two or more system elements. 
Programmatic interfaces between the program, projects, operations, etc., will be controlled by Memoranda of Agreement (MOAs) for internal (LMHC) interfaces, and/or by contract modifications or agreements in principle (AIP) (per LMHC Contract Communication 007 of February 18, 1998) for interfaces with non-LMHC systems, structures or components. It should be noted that ICDs are reserved for technical interface control, while MOAs, contract modifications and AIPs are used for programmatic interfaces. Physical interfaces internal to subprojects will be developed and maintained in an informational format capable of turnover to operations.

\subsection{DATABASES}

Informational databases created within PI Program will be developed and maintained using the best management practices (i.e., one official database copy, identification of the database custodian, and full file backup on a routine basis).

As a program under TWRS, PI Program requirements will be maintained and controlled using the Hanford Site Technical Database (HSTD). See Section 3.2 for a detailed description of this requirement.

\subsection{PROCEDURES}

Description of $\mathrm{CM}$ and the basic actions to be taken by the PI Program in implementing CM, is provided in TWRS Administration, HNF-IP-0842, Volume IV, "Engineering," Section 2.13, "Tank Waste Retrieval Configuration Management." Emphasis will be placed on minimization of procedures and use of existing procedures where possible. If the procedure is deemed inadequate, it will be corrected prior to continuing its use.

Procedures written for the PI Program will be developed, issued, and maintained as supporting documents, per Supporting Document Requirements, HNF-PRO-439, Processing Project Hanford Procedures, HNF-PRO-589, and Processing Unclassified Information Products, HNF-PRO-697. Signature approval will be in accordance with Review and Approval of Documents, HNF-PRO-233.

\subsection{PROGRAM FLLE DEVELOPMENT AND MAINTENANCE}

A PI Program File will be developed and maintained to capture program related information, including, but not limited to, incoming/outgoing correspondence, delegation of authorities, internal memos, cc:mail, DSI's, Engineering Data Transmittals, Engineering Change Notices, conference notes, supporting documents, design drawings, meeting minutes, activity reports, telecons, and trip reports. 


\subsection{CONFIGURATION MANAGEMENT IMPLEMENTATION PLAN TRAINING}

Training on the concepts and processes of this CMIP will be presented to PI Program personnel, including vendors and subcontractors, as determined by the PI Program Manager. Records of attendance and session materials will be maintained in the PI Program File. Refresher training will be conducted as determined by Program Manager.

\subsection{PERFORMANCE AGREEMENTS}

Performance Agreements related to the PI Program will be controlled as part of the contractual baseline. During the course of working a Performance Agreement, impacts may occur that could require changes to the scope of work and the completion criteria. Changes to the programmatic baseline resulting from Performance Agreement changes are controlled via the TWRS Baseline Change Control, HNF-IP-0842, Volume VIII, Section 1.1,

\subsection{CONFIGURATION IDENTIFICATION}

PI Program management is responsible for ensuring that items and information important to the success of the program mission are identified and placed under CM control. These are known as configuration items and configuration information. The products of the PI Program will be evaluated against the CM scope criteria (see Section 2.3) to identify those products that will be configuration controlled. Control of changes to these items and information is further described in Section 5.0 of this plan. Figure 2 provides an overview of the application of $\mathrm{CM}$ to PI Program products and services.

\subsubsection{Configuration Item Selection and Control}

Items will be selected for $\mathrm{CM}$ control based on their importance to the PI Program mission and on the risks resulting from product inadequacy. These risks include potential impacts to programmatic and technical baselines, deliverables, and related systems, structures, and components. These items and their dependencies will be identified as configuration items by examining their uses and relationships in program logics, and by comparisons against the selection criteria listed in TWRS CMP, HNF-1900 (Vann et al. 1998). Documentation justifying a decision to not control an item must be maintained. 
HNF-3046

\section{Revision 0}

Figure 2. Configuration Management Process Flow.

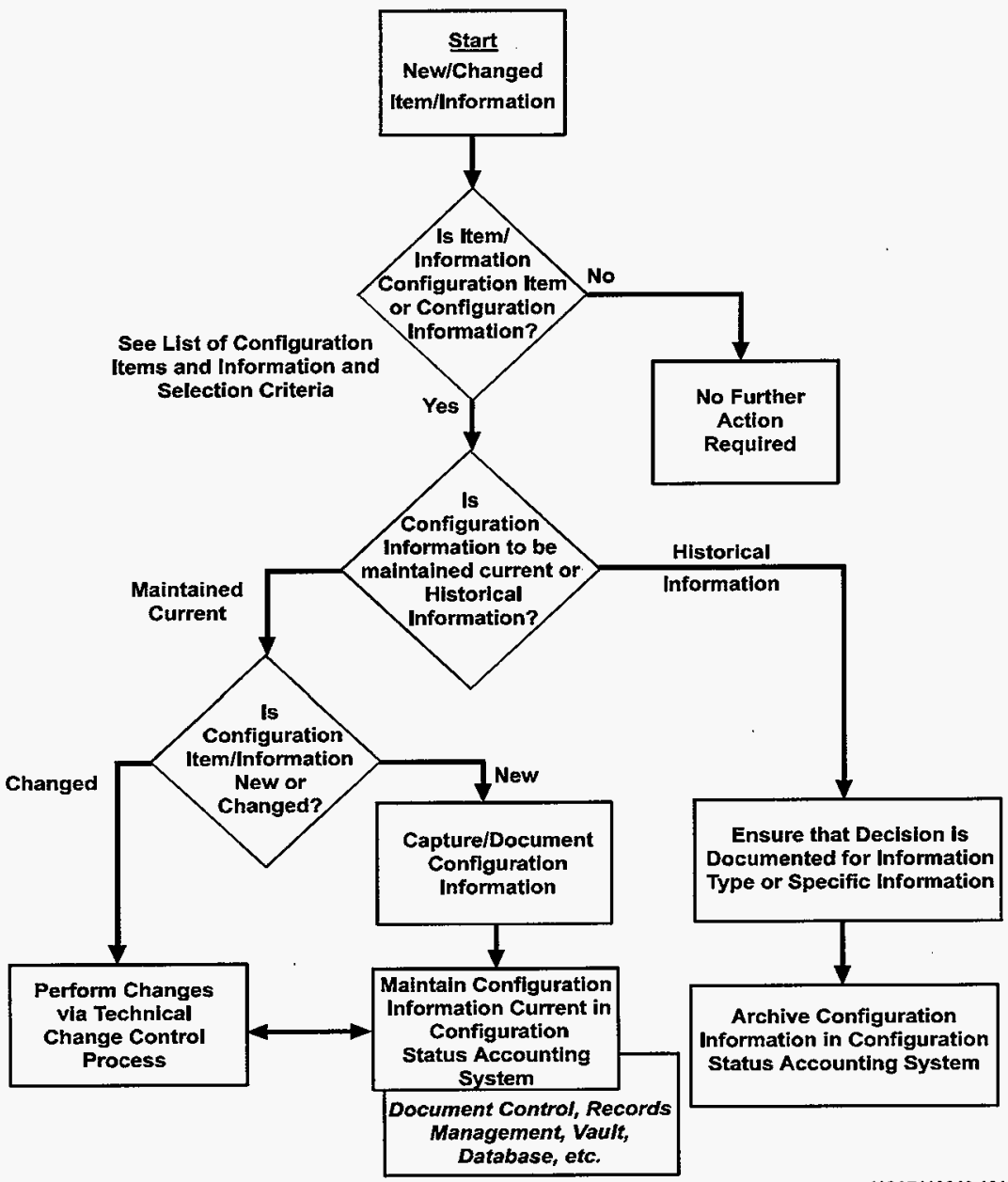




\subsubsection{Configuration Information Selection and Control}

Configuration information is documentation that defines, provides a basis for, or otherwise has an important relationship to, a configuration item or other configuration information. This includes design drawings, engineering procedures, specifications, MOAs, system design descriptions, processes, safety analysis reports, operations and maintenance procedures and manuals, as-built drawings, equipment and component lists, analyses and calculation reports, systems engineering documents and vendor information. The cognizant engineer determines the types of documents to be included in the CM program, based upon the criteria provided in this plan. Selected documents will identify the cognizant engineer, and will be identified (numbered) in accordance with Engineering Document Identification, HNF-PRO-227, to facilitate control and retrieval.

The Program will control technical, schedule, and cost data used to acquire, build, and otherwise support the item throughout its life cycle. This includes information received as an input to the program, as well as information derived internally by the program. It further includes current information maintained to support the Program, as well as information that will be archived. The design basis will be identified and maintained traceable to the configuration item and related design documents. Changes to the design basis will be evaluated to determine impacts and required design changes.

\subsection{INTEGRATED BASELINE--ALLOCATION OF REQUIREMENTS}

The Hanford Site Technical Baseline Database (HSTD) establishes the top-level functional requirements that define the Hanford Site cleanup mission. The baseline allocates requirements to TWRS, which in turn allocates requirements to its programs, defines primary interfaces, and bounds the mission of the TWRS. Program requirements, interface data and traceability data will be maintained in the HSTD.

The PI Program work activities are defined through Level 1 Logics (FDH 1998) and associated Technical Basis Reviews (TBRs) Level 7 of the Work Breakdown Structure (WBS). This documentation recognizes the current fiscal year (FY) 1998 configuration, while establishing the framework for configuration maturation of the work scope in accordance with schedules defined by the finalized privatization contract.

\subsection{INTEGRATED BASELINE SCHEDULE}

Each level of the baseline schedule is built to mirror the appropriate levels of the PI Program Technical Baseline. Relationships (predecessor/successor) and duration of activities have been identified and documented. Changes that affect the appropriate levels of the baseline schedule will be processed in accordance with "Program Administration," HNF-IP-0842, Volume VIII, Section 1.1, "TWRS Baseline Change Control." 


\subsection{BASELINE BUDGET PLAN}

Baseline budgets are established in the Integrated Baseline by resource loading the technical work scope identified in detailed schedules that drive the PI Program Master Baseline Schedule. The specific budgets resulting from this resource loading are based on the units (e.g., labor hours) of detailed planning assigned to the work and the values assigned to these units. The Baseline Budget Plan and supporting Financial Data System are configuration items. Changes to these configuration items, the elements that make up these items, or the elements these items support, will be controlled in accordance with "TWRS Baseline Change Control," HNF-IP-0842, Volume VIII, Section 1.1. 
HNF-3046

Revision 0

This page intentionally left blank. 
HNF-3046

Revision 0

\subsection{DESIGN REQUIREMENTS}

\subsection{ESTABLISHMENT OF DESIGN REQUIREMENTS}

The PI Program is evolving from a DRD that was generated by a word processing software package to a Level 2 Specification generated out of the HSTD. This document is the requirements basis for the program, and was developed using a systems engineering approach. The PI Program will maintain its technical baseline functions and requirements to a level of detail appropriate to its scope, as determined by the Program Manager.

The basis for design requirements will be established for each of the SSC identified as noted above in Section 2.3, "Equipment Scope Criteria." The SSC equipment list will include reference to design requirements documentation.

The body of technical information (e.g., requirements and design basis, reflected in drawings, specifications, process flow diagrams, vendor information, supporting documents, engineering studies, analyses) associated with systems under development, operation, modification or deactivation will be developed, verified and managed in accordance with the appropriate Hanford procedures (HNF-PROs) listed in Appendix C.

Applicable sections of Engineering Practices Guidelines, HNF-PRO-504, as determined by the subproject cognizant engineer, and management, will be implemented throughout the design process. Design verification (both final design and subsequent changes/revisions) will be in accordance with Design Verification Requirements, HNF-PRO-445. All engineering drawings will be prepared, approved, released, and revised per manual Engineering Drawing Requirements, HNF-PRO-242, with the exception of vendor drawings, that will be controlled by Vendor Information Requirements, HNF-PRO-444, and Fluor Daniel Northwest A/E Standard General Manual, Sections GG-DWG-001 through -004. Field verification will be in accordance with Engineering Drawing Requirements, HNF-PRO-242.

\subsection{REQUIREMENTS TRACKING}

PI Program requirements will be maintained and controlled using the Hanford Site Technical Database (HSTD).

\subsection{SYSTEM AND PROCESS BOUNDARIES}

Each system or process will be established to contain the components necessary to satisfy the design requirements for that system or process. The boundaries for each system or process will be defined and documented by controlled supporting documents, drawings, or specifications. 


\subsection{ASSIGNMENT OF STRUCTURES, SYSTEMS, AND COMPONENTS SAFETY GRADES}

The HNF-PRO-516, PHPP Safety SSC will be used to identify whether SSCs are safety class (SC) or safety significant (SS). The safety class will be used as the basis for the degree of control imposed on the SSC.

\subsection{SAFETY EQUIPMENT LISTS}

Based on the safety classification assigned to each SSC, a Safety Equipment List (SEL) will be developed in accordance with "Compiling the Safety Equipment List," Section 3.2., HNF-PRO-516. If the subproject has or will develop a master equipment list, the SEL may be part of the larger list. 
HNF-3046

Revision 0

\subsection{DOCUMENT CONTROL and STATUS ACCOUNTING}

PI Program related documents containing design related information will be developed, reviewed, and released into the Hanford Site document control system by use of an Engineering Data Transmittal, and processed by an authorized Document/Information Management Center (DIMC), in accordance with the document and record management procedures listed in Section 3.1 above, and Records Management, HNF-PRO-208; Document Control, HNF-PRO-224; and Project and Task Document Management, HNF-PRO-232. Authorized signature levels will be determined in accordance with Review and Approval of Documents, HNF-PRO-233.

Program configuration documents will be controlled in accordance with applicable procedures. Only currently approved revisions of configuration controlled documents will be used to conduct work. The PI Program will have a designated DIMC that will process and maintain its documents. A PI Program file will also be established within its designated DIMC to retain programmatic, project, sub-element, and subcontractor information and will be maintained through guidance from PI Program management. The document control and records management systems will further comply with the appropriate Hanford procedures.

\subsection{DOCUMENT/INFORMATION CONTROL SYSTEMS AND FACILITIES}

The PI Program will use its designated DIMC to receive and transmit documentation and information associated with the Program's mission. The DIMC will provide a document management and digitizing (electronic imaging) process to reduce the volume of paper and enable automating and streamlining of the business process, and will provide the technology and services to manage both internally and externally created documents so that information is readily accessible across the enterprise. This documentation and information process will be defined in desk instructions and procedures to be developed by the PI Program, as necessary.

The DIMC will provide document scanning, indexing, document release, document clearance, distribution, storage, records disposition and transfer, commitment tracking and other services as required. PI Program documentation will be stamped and logged as it is processed through the DIMC. Documents not stamped by DIMC must be forwarded to DIMC for processing. PI Program correspondence and documents will obtain letter and document numbers from DIMC. The DIMC document and information process flow is described in TWRS CMP, HNF-1900 (Vann et al. 1998).

Information systems utilized to implement the PI Program CM program are identified in the Configuration Management Information Systems Project Document, HNF-SD-TWR-CSWD-001 (Gneiting 1997). Improvements and upgrades of the Program's information systems will occur on an as-needed basis or through larger initiatives (such as the HANDI 2000 initiative). PI Program CM information systems will comply with requirements contained and referenced in this CMIP. 


\subsection{CONFIGURATION STATUS ACCOUNTING}

Status accounting of configuration items utilizes the above described information system to list and status configuration items and associated configuration information, including the item/information identifier, ownership (functional organization), and associated WBS element. The configuration status accounting system will identify baseline documents and their supplements including interface documents such as the MYWP, Performance Agreements and permits. As configuration items and information are identified, they will be entered into the configuration status accounting system. The system will evolve and its contents will be updated to provide a history and status throughout the configuration items' life cycle.

Configuration items and information will be deleted from the system by the appropriate change board as they are decommissioned, dismantled, discarded, destroyed, voided or superseded. A procedure will be developed during the third quarter of FY 1998, by the TWRS CM organization, to address the removal of controlled configuration items and information from the configuration status accounting system. 
HNF-3046

Revision 0

\subsection{CHANGE CONTROL}

Control of baseline changes is described in TWRS Change Control, LMH-MD-004 (Rosenberry 1997). The "A/B/C" change board system will be used by the PI Program for baseline management at the project/subproject level of the Work Breakdown Structure. Thresholds and change board membership are defined in Table 1 of the TWRS CMP, HNF-1900 (Vann et al. 1998).

\subsection{PROGRAMMATIC CHANGE CONTROL}

Changes that affect the Integrated Baseline will be processed and dispositioned in - accordance with "TWRS Baseline Change Control," HNF-IP-0842, Volume VIII, Section 1.1. This procedure applies to changes affecting the lower tier data that roll up to the technical, work scope, cost, and schedule baseline elements contained within the MYWP. Where MYWP changes impact the Baseline, changes will be processed in accordance with the change control process.

\subsection{TECHNICAL CHANGE CONTROL}

The current TWRS change control process incorporates front-end screening of proposed technical changes to evaluate potential impacts to cost and schedule baselines, establish levels of change control, and integrate the various change control processes. The approved configuration, changes, and departures are contained and tracked in the configuration status accounting system. Changes that affect technical products or technical information under $\mathrm{CM}$ will be controlled using this process. PI Program CM will be further defined by developing PI Program specific implementing procedures. 


\subsection{IDENTIFICATION OF CHANGES}

\subsubsection{Physical Changes}

Changes to physical configuration, design information, and documentation will be managed through the Engineering Change Notice (ECN) process as stated in Engineering Drawing Requirements, HNF-PRO-440. Procedure Preparation and Control Requirements for Engineering Drawings, GG-DWG-01, Section 2.15, "Drawing Approval and Initial Release" identifies an exception and its associated requirements for an offsite $A / E$ firm with engineering/design control to maintain configuration control until final As-Built turnover of drawing originals and associated data sets.

ECNs will be prepared according to HNF-PRO-440 instructions. The Title/No., Work Order No., Justification and Cost Impact, Schedule Impact, Change Impact and Other Affected Documents will be included, as a minimum, for all ECNs affecting physical configuration or design information.

Program baseline management and change control will be managed using the Change Request process in accordance with Baseline Management, HNF-PRO-523; Change Control, HNF-PRO-533; and Baseline Change Control, HNF-PRO-569. Implementation of the Hanford Site Management Control System ensures changes to baselines (cost, schedule, or scope change) are reviewed and approved by the appropriate level of management.

\subsection{CHANGE CONTROL PROCESS}

The PI Program will use the change control procedures described in TWRS Change Control, LMH-MD-004 (Rosenberry 1997).

\subsection{TECHNICAL REVIEWS}

Proposed changes affecting SSC and facility documentation will have technical reviews, and signature approvals consistent with Review and Approval of Documents, HNF-PRO-233. Technical reviews will verify that design basis and design requirements remain consistent and are not compromised; that all safety and mission impact requirements have been identified; that acceptance testing and operational and maintenance specifications have been developed or modified; and that affected/interfacing SSC and documentation are modified or reconciled.

\subsection{MANAGEMENT REVIEWS}

ECN approvals should be given the same organizational considerations as the document received at initial release, per Review and Approval of Documents, HNF-PRO-233. Signature 
HNF-3046

Revision 0

will indicate that the change is necessary, of beneficial use, and conforms to this CMIP.

\subsection{POST MODIFICATION TESTING}

Released ECNs will be incorporated at the completion of required testing, maintenance and operations checkout, in accordance with Testing Requirements, HNF-PRO-446, and Engineering Drawing Requirements, HNF-PRO-440, to determine if the equipment meets design requirements. As-building required for SSCs will be in accordance with, Engineering Drawing Requirements, HNF-PRO-242. 
HNF-3046

Revision 0

This page intentionally left blank. 


\subsection{CONFIGURATION MANAGEMENT ASSESSMENTS}

\subsection{PROGRAMMATIC ASSESSMENTS}

The TWRS CM organization and the TWRS Quality Assurance organization will perform assessments for compliance to the CM program. Assessments will be performed for each CM element to determine if the upgraded programs and procedures address identified weaknesses, are effective in accomplishing the $\mathrm{CM}$ functions, and are workable. Assessments will be planned to determine the strengths and weaknesses of existing CM-related programs and procedures with regard to determining where upgrade actions and resources are necessary.

\subsection{PROGRAM AND PROJECT LEVEL CONFIGURATION MANAGEMENT ASSESSMENTS}

To ensure facility specific physical configuration, an initial assessment will be conducted to ensure the establishment and maintenance of technical consistency among design requirements, physical configuration and documentation. Facility specific plans may choose to implement the assessment process by use of Standard Operating Practices, HNF-PRO-559.

\subsection{PHYSICAL CONFIGURATION ASSESSMENTS}

Physical configuration assessments, or walkdowns, will be performed for a representative sample of SSCs to determine the degree of agreement between the physical configuration and the configuration depicted in the facility document. The TWRS has initiated a Drawing and Labeling program that is identifying and labeling Tank Farm equipment and updating the essential drawings of the Tank Farms where they are being as-built and Engineering Change Notices are being incorporated. This effort can be considered as an ongoing CM assessment, but the TWRS CM planning schedule will identify additional assessments.

\subsection{PERIODIC EQUIPMENT PERFORMANCE MONITORING}

The performance of SSC identified in the SEL will be assessed by the Work Management Manual, IP-1217, and will be analyzed by the cognizant engineer to determine any required recommendations relative to repair and/or replacement. 
HNF-3046

Revision 0

\subsection{MATERIAL CONDITIONING AND AGING MANAGEMENT}

Material condition and aging (MCA) will be identified for SSCs on the SEL. MCA information will be available for inclusion in operations and maintenance manuals (OMM). MCA information for SSCs on the Master Equipment List(s) should be considered for inclusion to routine maintenance manuals, and OMMs. 
HNF-3046

Revision 0

\subsection{SUMMARY}

As a program under TWRS, the PI Program is responsible for controlling its portion of the TWRS baseline and enhancing CM implementation within the program. Procedures will be developed, as described herein, to ensure the control of the baseline and changes (identified, developed and then maintained). As such, this plan was developed as a subtier document to the TWRS CMP (Vann et al. 1998). 
HNF-3046

Revision 0

This page intentionally left blank. 
HNF-3046

Revision 0

\section{APPENDIX A}

\section{ACRONYMS AND DEFINITIONS}

$\begin{array}{ll}\text { AIP } & \text { Agreements in Principle } \\ \text { CM } & \text { Configuration Management } \\ \text { CMP } & \text { Configuration Management Plan } \\ \text { CMIP } & \text { Configuration Management Implementation Plan } \\ \text { DOE } & \text { U.S. Department of Energy } \\ \text { DIMC } & \text { Document/Information Management Center } \\ \text { ECN } & \text { Engineering Change Notice } \\ \text { EDT } & \text { Engineering Data Transmittal } \\ \text { FDH } & \text { Fluor Daniel Hanford, Inc. } \\ \text { FY } & \text { Fiscal Year } \\ \text { HLW } & \text { High-Level Waste } \\ \text { HNF-PRO } & \text { Hanford Procedure } \\ \text { HSTD } & \text { Hanford Site Technical Database } \\ \text { ICD } & \text { Interface Control Document } \\ \text { LMHC } & \text { Lockheed Martin Hanford Corporation } \\ \text { MCA } & \text { Material Condition and Aging } \\ \text { MYWP } & \text { Multi-Year Work Plan } \\ \text { OMM } & \text { Operations and Maintenance Manual } \\ \text { PHMC } & \text { Project Hanford Management Contract } \\ \text { PHPP } & \text { Project Hanford Procedures and Policies } \\ \text { PC } & \text { Privatization Contractor } \\ \text { PI } & \text { Privatization Infrastructure } \\ \text { RL } & \text { U.S. Department of Energy-Richland Office } \\ \text { SAR } & \text { Safety Analysis Report } \\ \text { SEL } & \text { Safety Equipment List } \\ \text { SSC } & \text { Systems, Structures, and Components } \\ \text { TBR } & \text { Technical Basis Review } \\ \text { TBSD } & \text { Technical Baseline Summary Description } \\ \text { TWRS } & \text { Tank Waste Remediation System } \\ \text { USQ } & \text { Unreviewed Safety Question } \\ \text { WBS } & \text { Work Breakdown Structure } \\ & \end{array}$

Should--in this document denotes a guideline, a suggested practice that is not mandatory.

Will--in this document denotes a statement of fact, generally describing an action performed in compliance with a requirement imposed by a referenced higher order document.

Database Custodian--An individual or organization assigned responsibility for establishing andmaintaining configuration control of a database. 
Design Authority--The person uniquely responsible and accountable for final acceptability of a structure, system, subsystem, or component, including its technical baseline and safe operation. (Basis: AP 6-004) The Design Authority is responsible for all technical requirements, and ensures the design authority responsibilities are distributed to the lowest practical level within the subprojects.

Systems, Structures, and Components (SSCs)--Systems are collections of components assembled to perform a function such as piping, cable trays, conduit, or HVAC. Structures are elements that provide support or enclosure such as buildings, free standing tanks, dikes, and stacks. Components are items of equipment such as pumps, valves, relays, or elements of a larger array such as computer software, lengths of pipe, elbow, or reducers. (Basis: HNF-PRO-504).

Technical Baseline--A configuration identification document, or a set of such documents, formally designated and approved at a specific time. (The time need not be the same for each document in the set.) Technical baselines, plus approved changes to those baselines, constitute the current configuration identification. (Basis: DOE 430.1) 
HNF-3046

Revision 0

APPENDIX B

PRIVATIZATION INFRASTRUCTURE PROGRAM CONFIGURATION MANAGEMENT ROLES AND RESPONSIBILITIES

\section{Privatization Infrastructure Program Manager}

The Privatization Infrastructure Program Manager will ensure the provisions of this plan are implemented by:

1. Serving as or appointing a program design authority, responsible for ensuring the adequacy of engineering design processes and design documentation produced by that process.

2. Implementing and managing the CM program in accordance with this plan.

3. Ensuring that complete, accurate, and valid engineering documentation (drawings, text documents and vendor information) is developed and maintained, consistent with physical configuration, using a graded approach.

4. Maintaining overall control of all Privatization Infrastructure Program engineering documentation.

5. Ensuring cognizant adequate engineering support is provided in accordance with the engineering process guidelines of Engineering Practice Guidelines, HNF-PRO-504, and of this plan.

6. Ensuring change control procedures are used to maintain technical consistency among the requirements, physical configuration, and documentation.

7. Ensuring the necessary approvals and reviews are obtained for appropriate engineering documents.

8. Ensuring assessments are conducted to measure the adequacy of specific configuration management functions and the effectiveness of the $\mathrm{CM}$ process in establishing and maintaining basic technical relationships.

\section{Cognizant Engineer/Technical Leads}

In addition to the duties identified in Engineering Practice Guidelines, HNF-PRO-504, the cognizant engineer will: 
HNF-3046

Revision 0

1. Ensure appropriate approvals and reviews are obtained for original designs and subsequent changes.

2. Assist in the development and maintenance of the approved technical SSC scope.

3. Identify and manage technical boundaries and interface characteristics.

\section{Quality Assurance}

Quality Assurance will:

1. Develop audit plans, checklists and assessment criteria, and conduct periodic assessments of the CM requirements and their implementation.

2. Verify that procedures related to $\mathrm{CM}$ are implemented in accordance with $\mathrm{DOE}$, PHMC and LMHC and TWRS requirements and procedures.

3. Participate in the $\mathrm{CM}$ process for change control and design verification through inspections, audits, and surveillance.

\section{Privatization Infrastructure Program CM Lead}

The Privatization Infrastructure Program Lead for CM will:

1. Develop Privatization Infrastructure Program specific CM plans, procedures and documentation upgrade processes, including processes for field verification and design reconstitution.

2. Ensure new or revised DOE, LMHC, and TWRS requirements are properly integrated within this program CM program.

3. Ensure compatibility between the Privatization Infrastructure Program CM program, the TWRS CM program, and the CM programs of interfacing elements (site, operations, etc.).

4. Ensure the recording and reporting status for technical documents and associated changes are adequately addressed and maintained in appropriate procedures and databases.

5. Conduct or participate in CM assessments. 
HNF-3046

Revision 0

APPENDIX C

REFERENCES

\section{Database}

Hanford Site Technical Baseline Database, database maintained by Lockheed Martin Hanford Corporation for Fluor Daniel Hanford, Inc., Richland, Washington.

\section{Standard}

DOE-STD-1073-93, Guide for Operational Configuration Management Programs, Including the Adjunct Programs of Design Reconstitution and Material Condition and Aging Management, U.S. Department of Energy, Washington, D.C.

\section{Procedures}

MRP-MP-599, Project Hanford Quality Assurance Program Description, Fluor Daniel Hanford, Inc., Richland, Washington.

HNF-PRO-208, Records Management, Fluor Daniel Hanford, Inc., Richland, Washington.

HNF-PRO-210, Records Management Program, Fluor Daniel Hanford, Inc., Richland, Washington.

HNF-PRO-222, Quality Assurance Records, Fluor Daniel Hanford, Inc., Richland, Washington.

HNF-PRO-224, Document Control, Fluor Daniel Hanford, Inc., Richland, Washington.

HNF-PRO-227, Engineering Document Identification, Fluor Daniel Hanford, Inc., Richland, Washington.

HNF-PRO-232, Project \& Task Document Managementation, Fluor Daniel Hanford, Inc., Richland, Washington.

HNF-PRO-233, Review and Approval of Documents, Fluor Daniel Hanford, Inc., Richland, Washington.

HNF-PRO-239, Design Analysis Report Requirements, Fluor Daniel Hanford, Inc., Richland, Washington. 
HNF-PRO-240, Engineering TADs/HOLDs, Fluor Daniel Hanford, Inc., Richland, Washington.

HNF-PRO-241, Engineering Specification Requirements, Fluor Daniel Hanford, Inc., Richland, Washington.

HNF-PRO-242, Engineering Drawing Requirements, Fluor Daniel Hanford, Inc., Richland, Washington.

HNF-PRO-243, Interface Control Requirements, Fluor Daniel Hanford, Inc., Richland, Washington.

HNF-PRO-244, Engineering Data Transmittal Requirements, Fluor Daniel Hanford, Inc., Richland, Washington.

HNF-PRO-309, Control of Computer Software, Fluor Daniel Hanford, Inc., Richland, Washington.

HNF-PRO-317, Engineering Release \& Approval Requirements, Fluor Daniel Hanford, Inc., Richland, Washington.

HNF-PRO-344, Exemptions and Equivalencies, Fluor Daniel Hanford, Inc., Richland, Washington.

HNF-PRO-439, Supporting Document requirements, Fluor Daniel Hanford, Inc., Richland, Washington.

HNF-PRO-440, Engineering Document Change Control Requirements, Fluor Daniel Hanford, Inc., Richland, Washington.

HNF-PRO-441, Engineering Procurement Waiver Requirements, Fluor Daniel Hanford, Inc., Richland, Washington.

HNF-PRO-442, Design Control Requirements, Fluor Daniel Hanford, Inc., Richland, Washington.

HNF-PRO-444, Vendor Information Requirements, Fluor Daniel Hanford, Inc., Richland, Washington.

HNF-PRO-445, Design Verification Requirements, Fluor Daniel Hanford, Inc., Richland, Washington.

HNF-PRO-446, Test Requirements, Fluor Daniel Hanford, Inc., Richland, Washington.

HNF-PRO-464, Software Control, Fluor Daniel Hanford, Inc., Richland, Washington. 
HNF-3046

Revision 0

HNF-PRO-504, Engineering Practices Guidelines, Fluor Daniel Hanford, Inc., Richland, Washington.

HNF-PRO-509, Safety Analysis Process, Fluor Daniel Hanford, Inc., Richland, Washington.

HNF-PRO-511, Hazard Classification of Facilities and Segments, Fluor Daniel Hanford, Inc., Richland, Washington.

HNF-PRO-516, Safety Structures, Systems, and Components, Fluor Daniel Hanford, Inc., Richland, Washington.

HNF-PRO-523, Baseline Management, Fluor Daniel Hanford, Inc., Richland, Washington.

HNF-PRO-533, Change Control, Fluor Daniel Hanford, Inc., Richland, Washington.

HNF-PRO-552, Project Control, Fluor Daniel Hanford, Inc., Richland, Washington.

HNF-PRO-559, Standard Operating Practices, Fluor Daniel Hanford, Inc., Richland, Washington.

HNF-PRO-569, Baseline Change Control, Fluor Daniel Hanford, Inc., Richland, Washington.

HNF-PRO-589, Processing Project Hanford Procedures, Fluor Daniel Hanford, Inc., Richland, Washington.

HNF-PRO-656, Managing Data and Information, Fluor Daniel Hanford, Inc., Richland, Washington.

HNF-PRO-697, Processing Unclassified Information Products, Fluor Daniel Hanford, Inc., Richland, Washington.

IP-1217, Work Management Manual, Fluor Daniel Hanford, Inc., Richland, Washington.

\section{Logic Diagrams}

FDH, 1998, Logic Diagrams, prepared by Lockheed Martin Hanford Corporation for Fluor Daniel Hanford, Inc., Richland, Washington.

\section{Documents}

Acree, C. D., Jr., 1998, Tank Waste Remediation System Mission Analysis Report, HNF-SD-WM-MAR-008, Rev. 2, prepared by Lockheed Martin Hanford Corporation for Fluor Daniel Hanford, Inc., Richland, Washington. 
FDH, 1997, Multi-Year Work Plan, HNF-MD-017, Rev. 0, Fluor Daniel Hanford, Inc.; Richland, Washington.

FDNW, Fluor Daniel Northwest A/E Standard General Manual, Fluor Daniel Northwest, Richland, Washington.

Gneiting, B. C., 1997, Configuration Management Information System Systems Project Document, HNF-SD-TWR-CSWD-001, Rev. 0, prepared by Lockheed Martin Hanford Corporation for Fluor Daniel Hanford, Inc., Richland, Washington.

Lenseigne, D. L., 1997, Tank Waste Remediation System Fiscal Year 1998 Multi-Year Work Plan WBS 1.1, HNF-SP-1230, Rev. 0, prepared by Lockheed Martin Hanford Corporation for Fluor Daniel Hanford, Inc., Richland, Washington.

LMHC, 1997, TWRS Administration, HNF-IP-0842, Fluor Daniel Hanford, Inc., Richland, Washington.

Peck, L. G., 1998, Tank Waste Remediation System Systems Engineering Management Plan, HNF-SD-WM-SEMP-002, Rev. 1, prepared by Lockheed Martin Hanford Corporation for Fluor Daniel Hanford, Inc., Richland, Washington.

Rosenberry, M. W., 1997, TWRS Change Control, LMH-MD-004, Rev. 0, Lockheed Martin Hanford Corporation, Richland, Washington.

Vann, J. M., E. R. Hamm, and R. D. Crisp (MACTEC), 1998, Tank Waste Remediation System Configuration Management Plan, HNF-1900, Rev. 0, prepared by Lockheed Martin Hanford Corporation for Fluor Daniel Hanford, Inc., Richland, Washington. 


\section{DISTRIBUTION SHEET}

\begin{tabular}{|c|c|c|c|c|c|}
\hline \multirow{2}{*}{$\begin{array}{l}\text { To } \\
\text { Distribution }\end{array}$} & \multirow{2}{*}{\multicolumn{3}{|c|}{$\begin{array}{l}\text { From } \\
\text { P. S. Schaus, LMHC }\end{array}$}} & \multicolumn{2}{|l|}{ Page 1 of 1} \\
\hline & & & & \multicolumn{2}{|c|}{ Date $8 / 17 / 98$} \\
\hline \multirow{2}{*}{\multicolumn{4}{|c|}{$\begin{array}{l}\text { Project Title/Work Order } \\
\text { Tank Waste Remediation Systems Privatization Infrastructure } \\
\text { Program Configuration Management Implementation Plan, } \\
\text { HNF }-3046 \text {, Rev. 0 }\end{array}$}} & \multicolumn{2}{|c|}{ EDT No. 161499} \\
\hline & & & & \multicolumn{2}{|c|}{ ECN No. } \\
\hline Name & MSIN & $\begin{array}{l}\text { Text } \\
\text { With All } \\
\text { Attach. }\end{array}$ & Text Only & $\begin{array}{l}\text { Attach./ } \\
\text { Appendix } \\
\text { Only } \\
\end{array}$ & $\begin{array}{l}\text { EDT/ECN } \\
\text { Only }\end{array}$ \\
\hline $\begin{array}{l}\text { Central Files } \\
\text { DOE Reading Room } \\
\text { DIMC }\end{array}$ & $\begin{array}{l}\mathrm{B} 1-07 \\
\mathrm{H} 2-53 \\
\mathrm{R} 1-41\end{array}$ & $\begin{array}{l}X \\
X \\
X\end{array}$ & & & \\
\hline $\begin{array}{l}\text { S. K. Baker } \\
\text { H. L. Boston } \\
\text { D. L. Fort } \\
\text { P. A. Haine } \\
\text { B. J. Hende I } \\
\text { T. R. Hoertkorn (DOE) } \\
\text { S. S. Lowe } \\
\text { S. M. O'Toole } \\
\text { R. J. Parazin } \\
\text { G. R. Porter } \\
\text { R. W. Root } \\
\text { H. Rossi } \\
\text { P. S. Schaus } \\
\text { G. Singh } \\
\text { W. T. Thompson } \\
\text { J. M. Vann }\end{array}$ & $\begin{array}{l}\text { H5-49 } \\
\text { R2-53 } \\
\text { R3-47 } \\
\text { R3-47 } \\
\text { B1-45 } \\
\text { A2-22 } \\
\text { H6-06 } \\
\text { R2-89 } \\
\text { R3-47 } \\
\text { R3-47 } \\
\text { R2-53 } \\
\text { B1-45 } \\
\text { R2-89 } \\
\text { R3-47 } \\
\text { G3-21 } \\
\text { R1-04 }\end{array}$ & 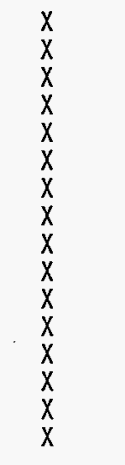 & . & & \\
\hline
\end{tabular}

